\title{
Ultrastructure, dissolution and "pyritization" of Late Quaternary and Recent echinoderms
}

\author{
MARGIT JENSEN \& ELSEBETH THOMSEN
}

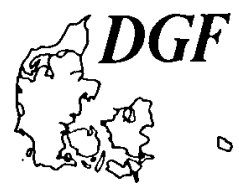

\begin{abstract}
Jensen, M. \& Thomsen, E.: Ultrastructure, dissolution and "pyritization" of Late Quaternary and Recent echinoderms. Bull. Geol. Soc. Denmark, vol. 36, pp. 275-287. Copenhagen. December 31st, 1987. https://doi.org/10.37570/bgsd-1988-36-09

The diagenetic history of the skeletal elements of Late Pleistocene-Holocene Ophiura sarsi from the shelf off northern Norway (Andfjorden, Malangsdjupet) is elucidated by comparison with natural and induced degradation of the skeletal elements of Recent ophiuroids (brittle stars) and asteroids (sea stars) from Danish waters.

Dissolution features ("core-and-rind") in the trabeculae of fossil and Recent echinoderm stereom are initiated during death and early decay of organic tissue in the animals. The trabeculae have a polycrystal-line lamellar ultrastructure and lose their older central part during later stages of dissolution, which are dependant on undersaturation of the sea-water with regard to $\mathrm{CaCO}_{3}$. The presence of undersaturated sea-water is supported by palaeoecological studies (Thomsen \& Vorren 1984, 1986) implying oxygen deficient periods in the Late Pleistocene and an increased biogenic production in the Holocene.

Pyrite framboids are situated in the secondary voids within the trabeculae and in the pore space of the stereom of the Late Pleistocene elements. No pyrite is observed within the polycrystalline lamellar ultrastructure of the trabeculae. The Late Pleistocene "pyritization" took place during oxygen deficient periods at the sediment-water interface or within the reduced zone of the topmost sediment.
\end{abstract}

Margit Jensen, Zoological Museum, Universitetsparken 15, DK-2100 Copenhagen $\emptyset$, Denmark. Elsebeth Thomsen, Institute of Geology, University of Oslo, P.O. Box 1047 Blindern, N-0316 Oslo 3, Norway. February 17th, 1987.

\section{Introduction}

Skeletal elements of echinoderms occur frequently in Late Pleistocene-Holocene glaciomarine/marine sequences from Andfjorden and Malangsdjupet (Thomsen \& Vorren 1986). Andfjorden and Malangsdjupet are deep glacial troughs that transverse the continental shelf off northern Norway (fig. 1). In the Late Pleistocene (i.e. after 19.000 years B.P.) Arctic conditions prevailed in the area. About 10.000 years B.P. the Atlantic water of the Norwegian Current intruded the troughs and caused a major faunal change, replacing the Arctic fauna with a Boreal fauna which developed into the recent High-Boreal fauna (Thomsen \& Vorren 1986).

The skeletal elements often showed degradation features and some times also "pyritization". The purpose of the present paper is (1) to elucidate the diagenetic history of the elements and (2) to discuss the accordance of the results with the previous palaeoecological interpretation of the Late Pleistocene-Holocene environment by Thomsen \& Vorren $(1984,1986)$.
This we have attempted by studying the ultrastructure of the stereom of Recent ophiuroids (brittle stars) and by comparing the degradation features in the fossil ophiuroids with natural and induced degradation in Recent ophiuroids and asteroids (sea stars).

\section{Material and methods}

Ossicles and jaws of fossil adult Ophiura sarsi (Lütken) were collected from two gravity cores (79-T-25-3 from Andfjorden and 79-T-56-1 from Malangsdjupet) sampled in 1979 by the University of Tromsø (fig. 2). The material was washed in fresh water and air-dried.

Ossicles and jaws of Recent echinoderms used in this investigation were from preserved specimens of Ophiura sarsi from Nordre Strømfjord, Greenland and from living specimens of $O$. texturata Lamarck, $O$. albida Forbes, $O$. robusta Ayres, Amphiura filiformis (Müller), A. chiajei Forbes and Asterias rubens Linné from the Sound, Denmark. Specimens of Crossaster pap- 


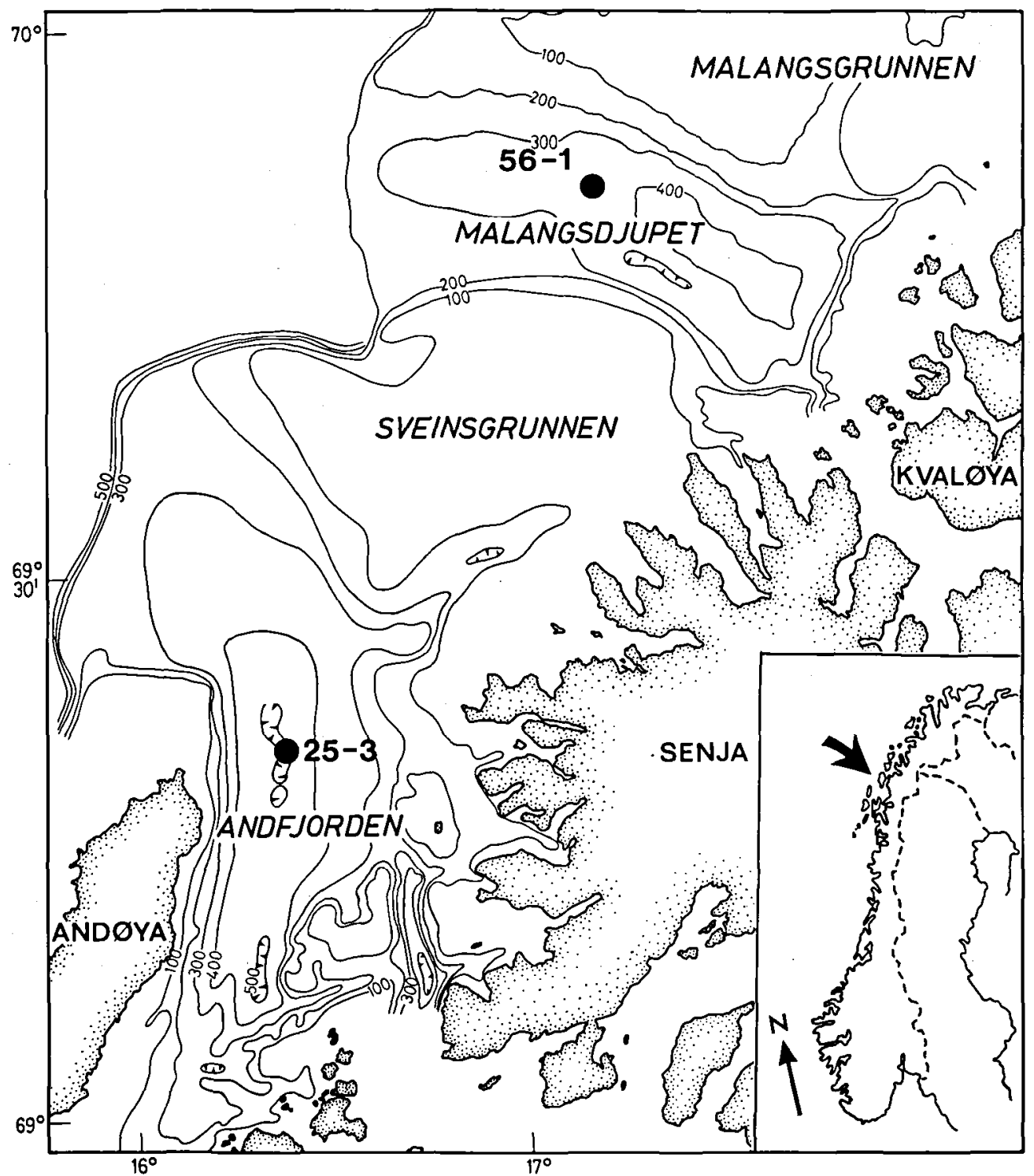

Fig. 1. Location of the investigated gravity cores.

posus (Linné) from the Sound were used as predator in the feeding experiments with living $A$. rubens. 2-5 specimens of each species were included in this investigation.

$O$. sarsi is a Boreo-Arctic species, the other brittle stars are Boreo-Lusitanian species (Mortensen 1924). A. rubens is an Arctic-Lusitanian species and $C$. papposus is a Boreo-Arctic species (Mortensen 1924). The Ophiura species live in the topmost layer of soft level-bottoms, e.g. $O$. texturata (Feder 1981), and the two Amphiura species live burrowed deeper in the sediment (Ockelmann \& Muus 1978). A. rubens and $C$. papposus live on rocks and stone "reefs" (Mortensen 1924).

In order to compare the experimentally induced degradation of the skeletal elements of Recent echinoderms with that of fossil echinoderms, some specimens of $O$. texturata and $A$. filiformis were killed in $80 \%$ ethanol, washed in distilled water, immersed in $5 \%$ sodium hypochlorite for $10 \mathrm{~min}$ and washed in distilled water. 


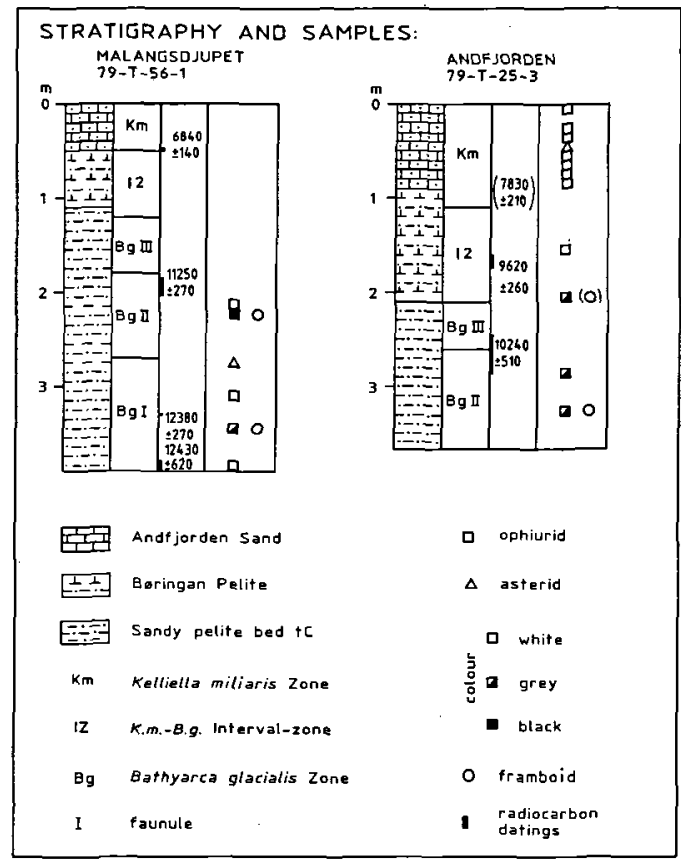

Fig. 2. Lithostratigraphy, biostratigraphy, radiocarbon datings and sampling of the studied cores. Note that the colour of the elements and the presence of framboids are given.

The ossicles and jaws were treated with different dissolving agents (table 1), washed several times in distilled water, immersed in $80 \%$ ethanol and air-dried. Old material of $O$. sarsi from the Zoological Museum, University of Copenhagen, was treated in the same way. Other specimens of $O$. texturata (arms only) and specimens of $O$. albida, $O$. robusta and $A$. chiajei were left dying and rotting in a glass jar with sea water (table 2). After 18 days rotting, the ossicles and jaws were washed several times in distilled water, immersed in $80 \%$ ethanol and air-dried. Skeletal elements from specimens of $A$. rubens ejected from a specimen of Crossaster papposus after the normal period of digestion, were washed in distilled water, immersed in $80 \%$ ethanol and air-dried. Finally all skeletal elements were coated with gold for SEM studies (Cambridge Stereoscan and JSM 840).

The ultrastructure of the trabeculae was elucidated by etching with different agents (table 1 ).

\section{Structure of the echinoderm skeleton}

The skeleton of ophiuroids consists of a superficial and a deeper part. The superficial elements are the shields of the disk and arms and the deeper elements are the central ossicles (vertebrae) of the arms and the jaws. Each vertebral ossicle (fig. 3) originates from two ambulacral plates, which interdigitate medianly forming one unit. The skeleton of the intervertebral surfaces of the ossicles forms two large aboral and two smaller oral depressions covered by a fine labyrinthic stereom to which the intervertebral mus-

Table 1. Dissolution experiments on ossicles and jaws from Recent ophiuroids and asteroids to visualize the ultrastructure of the trabeculae of the stereom. Chemical experiments carried out at $21^{\circ} \mathrm{C}$. Feeding experiments at $11^{\circ} \mathrm{C}$.

\begin{tabular}{|c|c|c|c|c|c|c|c|c|c|c|c|c|c|c|}
\hline \multirow[t]{2}{*}{ Species } & \multicolumn{4}{|c|}{ Whole animal } & \multicolumn{5}{|c|}{ Ossicles and jaws } & \multicolumn{2}{|c|}{ Time } & \multicolumn{2}{|c|}{ Ossicles and jaws } & \multirow{2}{*}{$\begin{array}{c}\text { Predator } \\
\text { C. papposus }\end{array}$} \\
\hline & Sea-water & $\begin{array}{c}\mathrm{C}_{2} \mathrm{H}_{5} \mathrm{OH} \\
80 \%\end{array}$ & $\mathrm{H}_{2} \mathrm{O}$ & $\begin{array}{c}\mathrm{NaOCl} \\
5 \%\end{array}$ & Broken & $\mathrm{H}_{2} \mathrm{O}$ & $\underset{\%}{\mathrm{CH}_{3} \mathrm{COOH}}$ & $\underset{\%}{\mathrm{HCOOH}}$ & $\underset{\%}{\mathrm{HCl}}$ & Sec. & Days & $\mathrm{H}_{2} \mathrm{O}$ & $\begin{array}{c}\mathrm{C}_{2} \mathrm{H}_{5} \mathrm{OH} \\
80 \%\end{array}$ & \\
\hline O. sarsi & $x$ & $x$ & $x$ & $x$ & - & $x$ & 5 & - & - & 240 & - & $x$ & $\times$ & - \\
\hline O. texturata & $\times$ & - & - & - & - & - & - & - & - & - & 18 & $x$ & $x$ & - \\
\hline O. texturata & $\times$ & $\times$ & $x$ & $x$ & - & $x$ & - & - & - & - & - & - & $x$ & - \\
\hline O. texturata & & & & & $x$ & $x$ & - & - & - & - & - & - & $x$ & - \\
\hline O. texturata & & & & & - & $x$ & 1 & - & - & 120 & - & $x$ & $x$ & - \\
\hline O. texturata & & & & & - & $\times$ & 1 & $\rightarrow$ & - & 240 & - & $x$ & $x$ & - \\
\hline O. texturata & & & & & - & $x$ & 5 & - & - & 240 & - & $x$ & $x$ & - \\
\hline O. texturata & & & & & - & $x$ & - & 1 & - & 120 & - & $x$ & $x$ & - \\
\hline O. texturata & & & & & - & $x$ & - & - & 0.1 & 120 & - & $x$ & $x$ & - \\
\hline O. texturata & & & & & - & $x$ & - & - & 1 & 10 & - & $x$ & $x$ & - \\
\hline O. texturata & & & & & - & $x$ & - & - & 1 & 120 & - & $x$ & $x$ & - \\
\hline O. albida & $x$ & - & - & - & - & - & - & - & - & - & 18 & $x$ & $x$ & - \\
\hline O. robusta & $x$ & - & - & - & - & - & - & - & - & - & 18 & $x$ & $x$ & - \\
\hline A. filiformis & $x$ & $x$ & $x$ & $x$ & - & $x$ & - & - & - & - & - & - & $x$ & - \\
\hline A. filiformis & & & & & - & $x$ & 1 & - & - & 60 & - & $x$ & $x$ & - \\
\hline A. chiajei & $x$ & - & - & - & - & - & - & - & - & - & 18 & $x$ & $x$ & - \\
\hline A. rubens & - & - & - & - & - & - & - & - & - & & $4 \& 14$ & $x$ & $x$ & $x$ \\
\hline
\end{tabular}


Table 2. Starving and rotting ophiuroids in sea-water without sediment. Salinity $30 \%$. Temperature $21^{\circ} \mathrm{C}$.

\begin{tabular}{|c|c|c|c|c|c|c|c|c|c|}
\hline \multirow[t]{3}{*}{ Species } & \multicolumn{4}{|c|}{$\mathrm{pH}$ in sea-water } & \multicolumn{3}{|c|}{ Death } & \multirow{3}{*}{$\begin{array}{c}\begin{array}{c}\text { Autotomy } \\
\text { of arms }\end{array} \\
5\end{array}$} & \multirow{3}{*}{$\begin{array}{c}\begin{array}{c}\text { Killed in } \\
\mathrm{C}_{2} \mathrm{H}_{5} \mathrm{OH}\end{array} \\
10\end{array}$} \\
\hline & \multicolumn{7}{|c|}{ Days after initiation of experiment } & & \\
\hline & 0 & 5 & 10 & 23 & 3 & 5 & 10 & & \\
\hline o. texturata ( $2 \mathrm{sp}$. , arms) & 8.15 & 7.80 & 8.00 & 8.55 & - & $x$ & - & - & - \\
\hline O. albida (1 sp.) & 8.15 & 8.00 & 7.65 & 7.80 & - & - & $x$ & - & - \\
\hline O. albida (3 sp.) & 8.15 & 8.30 & 8.20 & 8.35 & - & - & - & $x$ & $x$ \\
\hline O. robusta (2 sp.) & 8.15 & 7.30 & 8.25 & 8.50 & - & $x$ & - & - & - \\
\hline A. chiajei (2 sp.) & 8.15 & 8.10 & 8.15 & 8.35 & $x$ & - & - & - & - \\
\hline Sea-water, control & 8.15 & 8.15 & 8.15 & 8.15 & - & - & - & - & - \\
\hline
\end{tabular}

cles are attached. The central area of the surfaces bears the intervertebral joints, which consist of coarse labyrinthic stereom. The intervertebral ligament is attached to the coarse stereom. The articulation areas are covered by dense, compact stereom. Connective tissue links the superficial arm shields to the ossicles. Collagenous fibres are attached to the coarse labyrinthic stereom of the sides of the ossicles.

The mesodermal echinoderm skeleton is made by sclerocytes (calcoblasts). Distal processes of the sclerocytes form the cytoplasmic sheath over young parts of the trabeculae, but split up on fully grown parts of the trabeculae (Heatfield \& Travis 1975, Märkel \& Röser 1985). The presence of an intraskeletal organic matrix in the echinoderm skeleton is still under dispute. Jensen (1969) demonstrated the occurrence of organic matter in the plates of echinoids by a heating technique. Pilkington (1969) suggested that an organic fraction may appear between microcrystals in echinoid spines and did find that the skeleton contained a nitrogenous organic fraction. Inoué \& Okasaki (1977) found 1\% intraskeletal

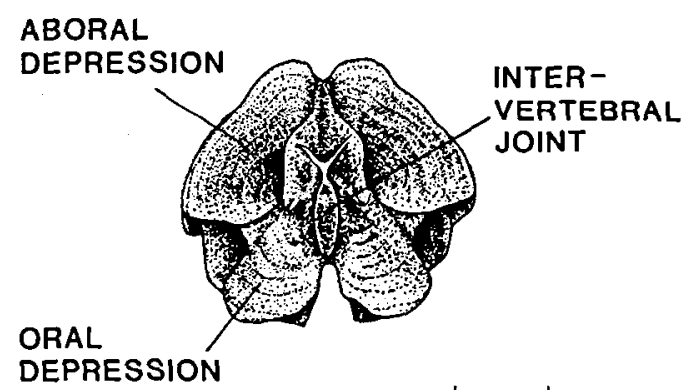

Fig. 3. Distal view of ossicle of Ophiura sarsi demonstrating morphological features. Camera lucida. Scale bar $1 \mathrm{~mm}$. organic matter in the larval spicule of an echinoid, and Weiner (1984) showed that the invertebrate organic matrices form a core of hydrophobic structural macromolecules (usually proteins) and surface layers of acidic proteins and polysaccharides.

The skeleton consists of high-Mg calcite composed of a three-dimensional mesh of trabeculae (stereom), which normally show cleavage structures on concoidal fractures (cf. Towe 1967, Nichols \& Currey 1968, Nissen 1969 and Jensen 1972 Plate 8 fig. 2).

The trabeculae have a polycrystalline lamellar ultrastructure (Travis 1969, 1970, O’Neill 1981). Shimizu \& Yamada (1976) found crystallites, rectangular or polygonal in shape, and varying in size from 0.1 to $3.5 \mu \mathrm{m}$, occasionally $5.5 \mu \mathrm{m}$ or more, in regenerating echinoid dermal tissue. Travis $(1969,1970)$ found two size-categories of crystals in echinoderm plates, one measuring $0.048 \mu \mathrm{m}$ in length and $0.007 \mu \mathrm{m}$ in width, and another measuring $0.2 \mu \mathrm{m}$ in length and 0.0145 $\mu \mathrm{m}$ in width, while the crystallites of O'Neill (1981) from an asteroid measured $0.36 \mu \mathrm{m}$ or more in length and $0.13 \mu \mathrm{m}$ in width and a lamella measured $0.2 \mu \mathrm{m}$ in width.

The interconnecting pore space of the sterom is filled with organic tissue (stroma).

The ultrastructure of the skeletal trabeculae in the stereom of the investigated Ophiura species is identical, within the range of magnification used in this study. However, the ultrastructure of the skeletal trabeculae in the stereom of the Amphiura species differs from that of the Ophiura species in being of a less compact ultrastructure. 

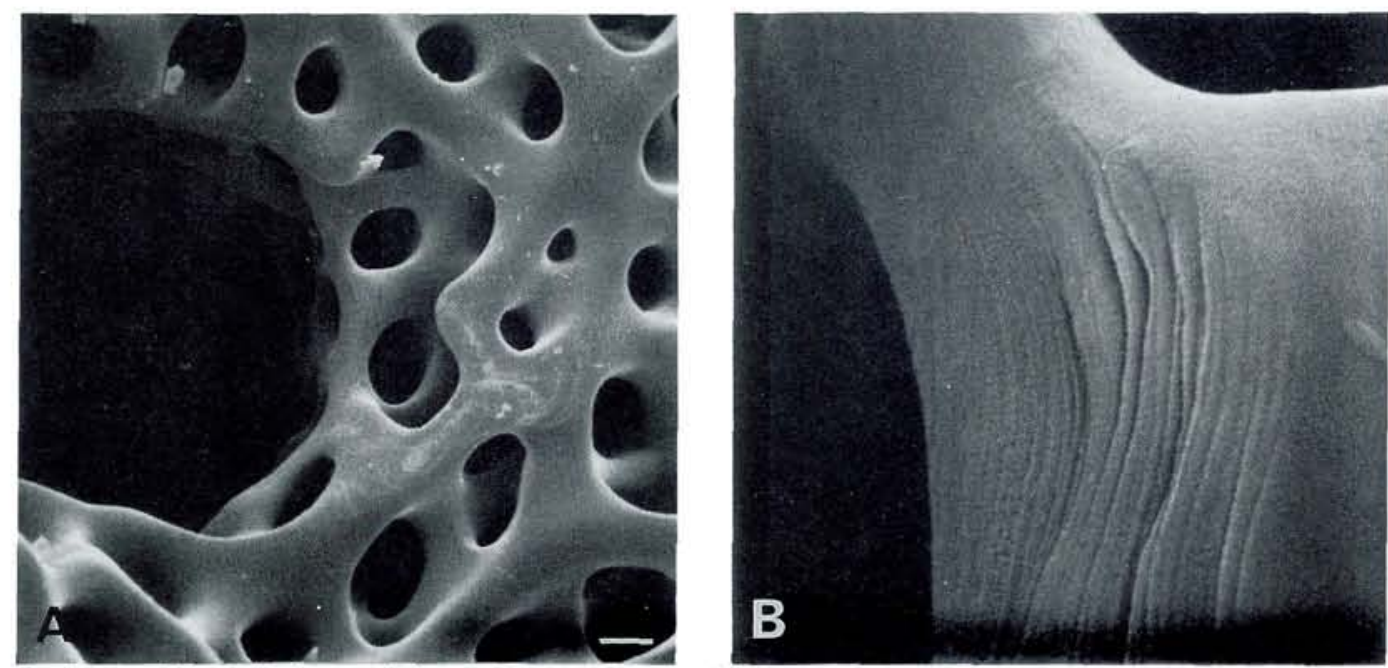

Fig. 4. Natural dissolution features in Recent Ophiura texturata ossicle. A. Dissolution of the trabeculae surrounding the pore hole of a tube foot. B. Close up of fig. 4A. Note the lamellar ultrastructure. Scale bar $1 \mu \mathrm{m}$ in A and $0.1 \mu \mathrm{m}$ in B.

\section{Dissolution of the echinoderm stereom}

Dissolution of the echinoderm stereom depends on the specific stereomic microstructure, the ultrastructure of the trabeculae, the high- $\mathrm{Mg}$ calcite mineralogy and internal factors such as phagocytosis. The $\mathrm{CaCO}_{3}$ saturation of the seawater/pore-water, exposure time at the sediment surface, the porosity and permeability of the sediment, as well as the depth of burial in the sediment, are environmental factors that influence the dissolution process significantly. In addition, predation and scavenging by other organisms may result in complete disintegration/dissolution.

\section{Natural dissolution}

Skeletal trabeculae of ossicles of $O$. texturata treated gently with sodium hypochlorite to remove all organic tissue on their surface show natural dissolution features on the trabeculae surrounding the pore holes for the tube feet (fig. $4 \mathrm{~A}$ ). Phagocytes dissolve the skeletal surface of the trabeculae and reveal the lamellar ultrastructure (fig. 4B).

\section{Induced dissolution}

Skeletal trabeculae of ossicles of $O$. texturata, $O$. robusta and $A$. chiajei from the rotting experiments (table 2) show different grades of dissolu- tion of the trabecular surface. The organic sheaths of young growing parts of the trabeculae are dissolved (fig. 5A). Older parts of the trabeculae have partly dissolved sheaths with cracks, which develop from small holes in a line (fig. 5B). The exposed skeletal surface of the trabeculae is dissolved forming deeper holes and cracks (fig. $5 \mathrm{C})$. The compact stereom of the ossicles shows these features earlier than does the labyrinthic stereom.

In order to investigate the dissolution caused by predation, i.e. by digestive enzymes, Crossaster papposus was fed with Asterias rubens, in an aquarium. Ejected ossicles of the latter show a random pitted dissolution of the trabecular surface (fig. 5D). According to Dr. Marianne Køie (pers. comn 1985) the skeleton of an ophiuroid will be completely dissolved in the stomach of a fish.

Skeletal trabeculae of the ossicles of $O$. sarsi, $O$. texturata and $A$. filiformis were treated with different dissolving agents (table 1). These trabeculae show a randomly pitted dissolution. The surface layer of the fine labyrinthic stereom in the intervertebral depressions has been deeply dissolved, almost etched away in parts of the areas (fig. 6A). The trabeculae in the lower layer of coarse labyrinthic stereom show the lamellar ultrastructure and the crystallite composition of the lamellae (fig. 6BC). The individual lamella measures approximately $0.1 \mu \mathrm{m}$ in width. A cracking 

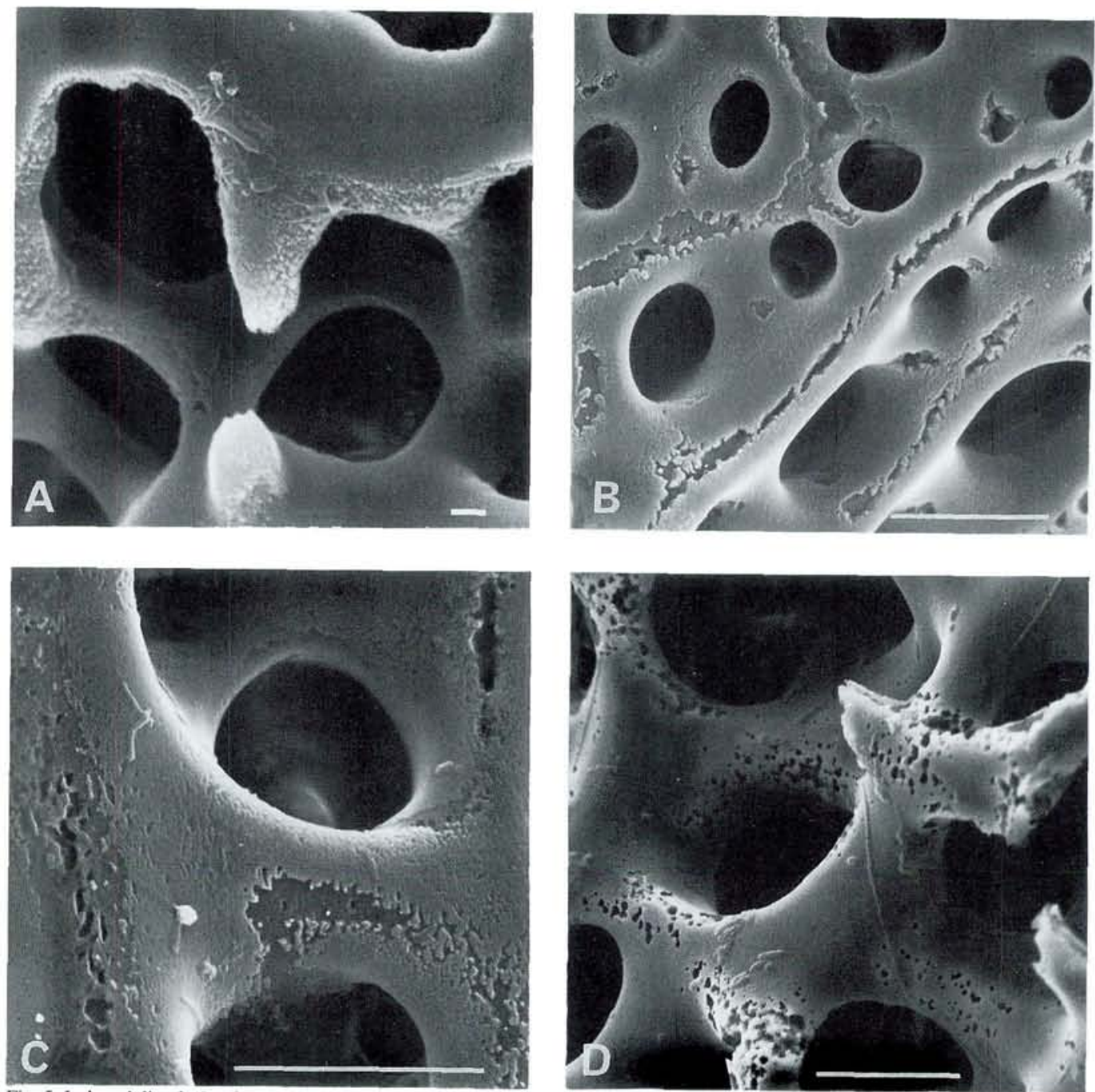

Fig. 5. Induced dissolution features in Recent echinoderms caused by rotting experiments (A-C) and predation (D). A. Dissolution of organic sheaths on the young growing parts of trabeculae in Ophiura texturata ossicle. B. Dissolution holes and cracks in the organic sheaths of the older parts of trabeculae in Amphiura chiajei ossicle. Note the similarity with "core-and-rind" features in fossil material of O. sarsi (e.g. in fig. 8B). C. Deeper holes and cracks are developed in the exposed trabecular surface of Amphiura chiajei jaw. D. Pitted dissolution of the trabecular surface of ossicle of Asterias rubens caused by digestive enzymes in the intestine of Crossaster papposus. Scale bar $1 \mu \mathrm{m}$ in A and $10 \mu \mathrm{m}$ in B-D.

pattern is developed in the compact stereom and the coarse labyrinthic stereom of the central area of the intervertebral surface of the ossicles (fig. $6 \mathrm{D})$. The cracks resemble karren fissures.

\section{Dissolution features in the fossil material}

Skeletal trabeculae of the fossil ossicles of $O$. sarsi show dissolution features. Finer labyrinthic stereom has been dissolved, and the trabeculae of the coarser stereom show different stages of a gradual increasing dissolution. This extends from thin superficial cracks - "core-and-rind" structures - to deeply dissolved trabeculae involving deep cracks and the loss of the central part (figs $7,8,9)$.

The cracks start as tiny grooves and develop a vermiform irregular course; they branch and anastomose (fig. 7A-E) in the otherwise smooth surface of the trabeculae. Trabeculae of the less 

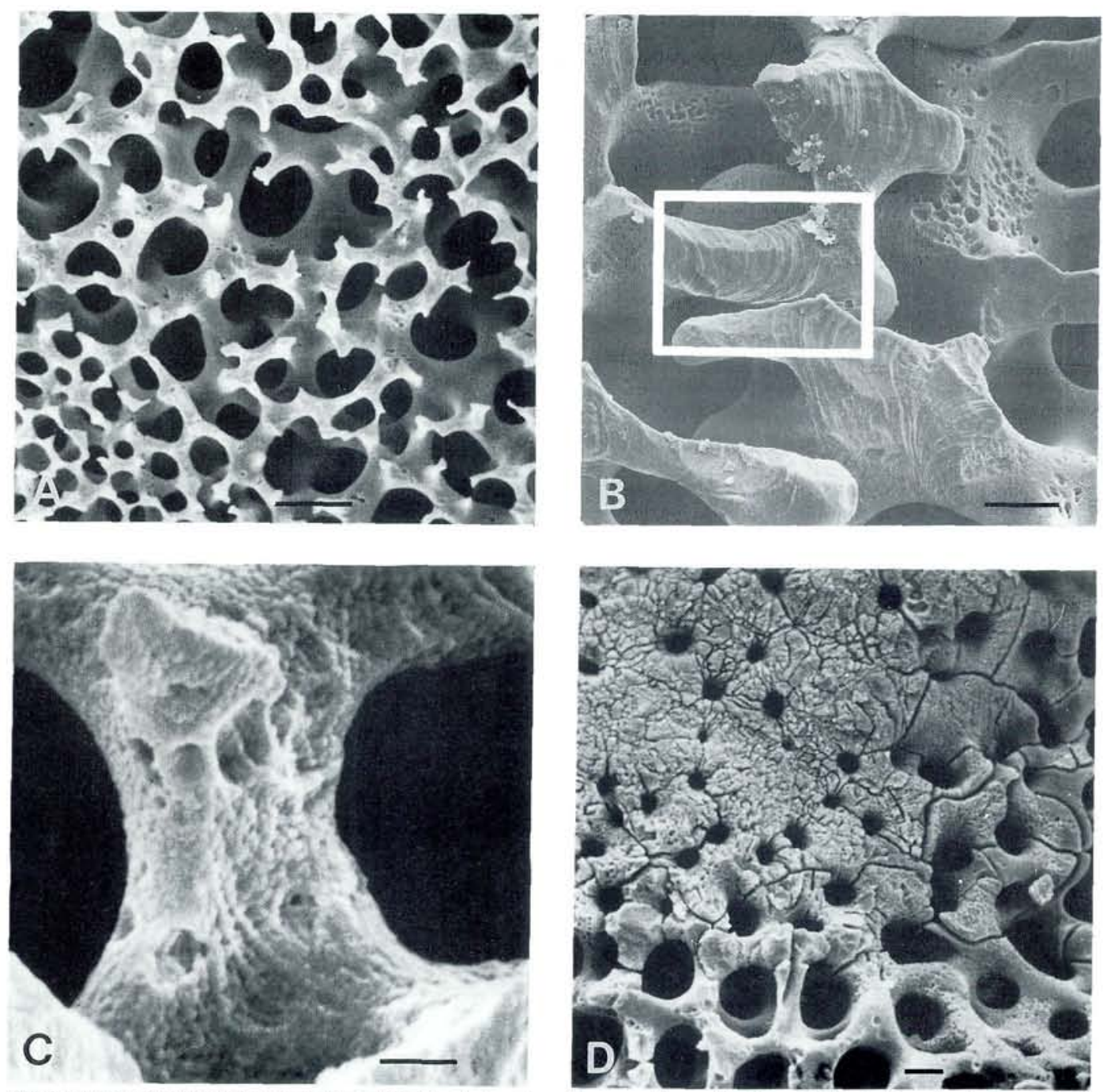

Fig. 6. Induced dissolution features in Recent Ophiura texturata ossicles caused by application of $\mathrm{HCl}$. A. Deep dissolution of the fine labyrinthic stereom and pitted trabecular surfaces ( $\mathrm{HCl} 1 \%$ for $10 \mathrm{sec}$.) B. Lamellar ultrastructure and crystallite composition in the coarse labyrinthic stereom ( $\mathrm{HCl} 1 \%$ for $240 \mathrm{sec}$.) C. As fig. $6 \mathrm{~B}$ ( $\mathrm{HCl} 1 \%$ for $10 \mathrm{sec}$.) D. Karstic cracking pattern in the compact stereom and in the coarse labyrinthic stereom ( $\mathrm{HCl} 1 \%$ for $10 \mathrm{sec}$.) Scale bar $1 \mu \mathrm{m}$ in A and D, $10 \mu \mathrm{m}$ in B and $0.1 \mu \mathrm{m}$ in $\mathrm{C}$.

dissolved ossicles have a limited number of thin (narrow) cracks in the surface (fig. 8A). Trabeculae that have been subjected to a prolonged dissolution show a broken surface, but have a large smooth intact surface around the pores (fig. $8 \mathrm{~B})$. Other trabeculae only show the remains of the upper surface layer, extending over the deeper layers as thin ridges (fig. $8 \mathrm{C}$, D). Deep and wide cracks in the trabeculae reveal the lamellar ultrastructure (fig. 9A, B). Strongly dissolved trabeculae form collars of the surface layer around the pores (fig. 9C) and others have lost their central part (fig. 9D). Pyrite framboids have been developed in the pore space and in the empty central parts of the dissolved trabeculae (fig 10A, B).

\section{Interpretation of the dissolution} features

The gradually developing dissolution features, the cracks, have previously been described by Alexandersson $(1975,1976,1978 a, b)$ in Recent 

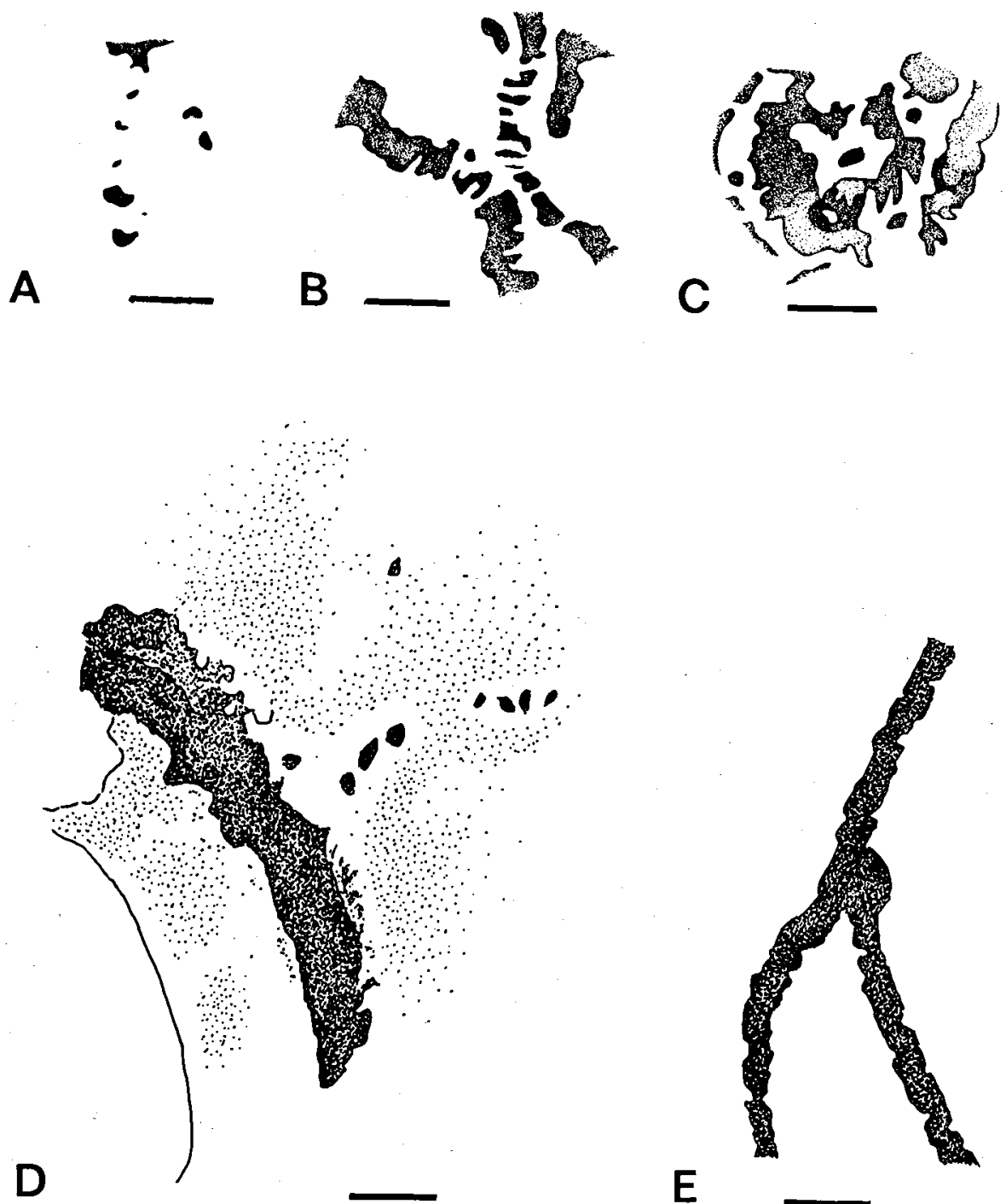

Fig. 7. The development of "core-and-rind" dissolution features in fossil Ophiura sarsi ossicles, drawn by camera lucida. A-C. Different stages of a gradual increasing dissolution. D. Branching. E. Anastomosing. Scale bar $2.5 \mu \mathrm{m}$ in A-C and E and $2 \mu \mathrm{m}$ in $\mathrm{B}$.

echinoderm material from the Skagerrak. Alexandersson regarded the structures as dissolution features caused by sea-water undersaturated with regard to $\mathrm{CaCO}_{3}$ and named them "coreand-rind" structures.

Our results from the experiments with rotting ophiuroids in stagnant sea-water (in the absence of sediment) show that these structures are developed during death and early decay of the organic tissue in the animals.

The $\mathrm{pH}$ value of stagnant sea-water containing animals and in the absence of sediment decreases until death of the animals and increases again after death (table 2). Death was caused by anoxia, the amphiurids dying as $\mathrm{pH}$ reached 8.10 whereas the ophiurids survived until a $\mathrm{pH}$ of 7.80 and 7.30 (table 2). Stagnant sea-water in glass jars lacking both animals and sediment had a constant $\mathrm{pH}$ of 8.15 throughout the experimental period, but after this period the $\mathrm{pH}$ increased owing to release of ammonia and bacterial decomposition (table 2).

Lactic acid is accumulated in the tissue of the brittle stars during the increasing oxygen deple- 
tion of the seawater owing to insufficient respiration and glycolysis. Amino acids are released. The microenvironment around the skeletal trabeculae becomes acid, and dissolution of the newly formed skeletal sheaths and tips is initiated. The areas of the trabeculae having the highest amount of organic matter show the strongest dissolution features, e.g. the growing tip of the trabeculae (fig. 5A), cf. also Heatfield \& Travis (1975: plate 9 figs 23, 24). Later, when ammonia is liberated from the amino acids the $\mathrm{pH}$ of the decaying tissue and the sea-water increases (table 2).

The later course in dissolution seen in fossil material, however, is dependant on undersaturation of the sea-water with regard to $\mathrm{CaCO}_{3}$, which has been described by Alexandersson (1975-1978). It takes place at the sediment-water interface and can probably also occur in the topmost sediment layer, depending on the porosity and permeability.

Dissolution by experimental application of dif-
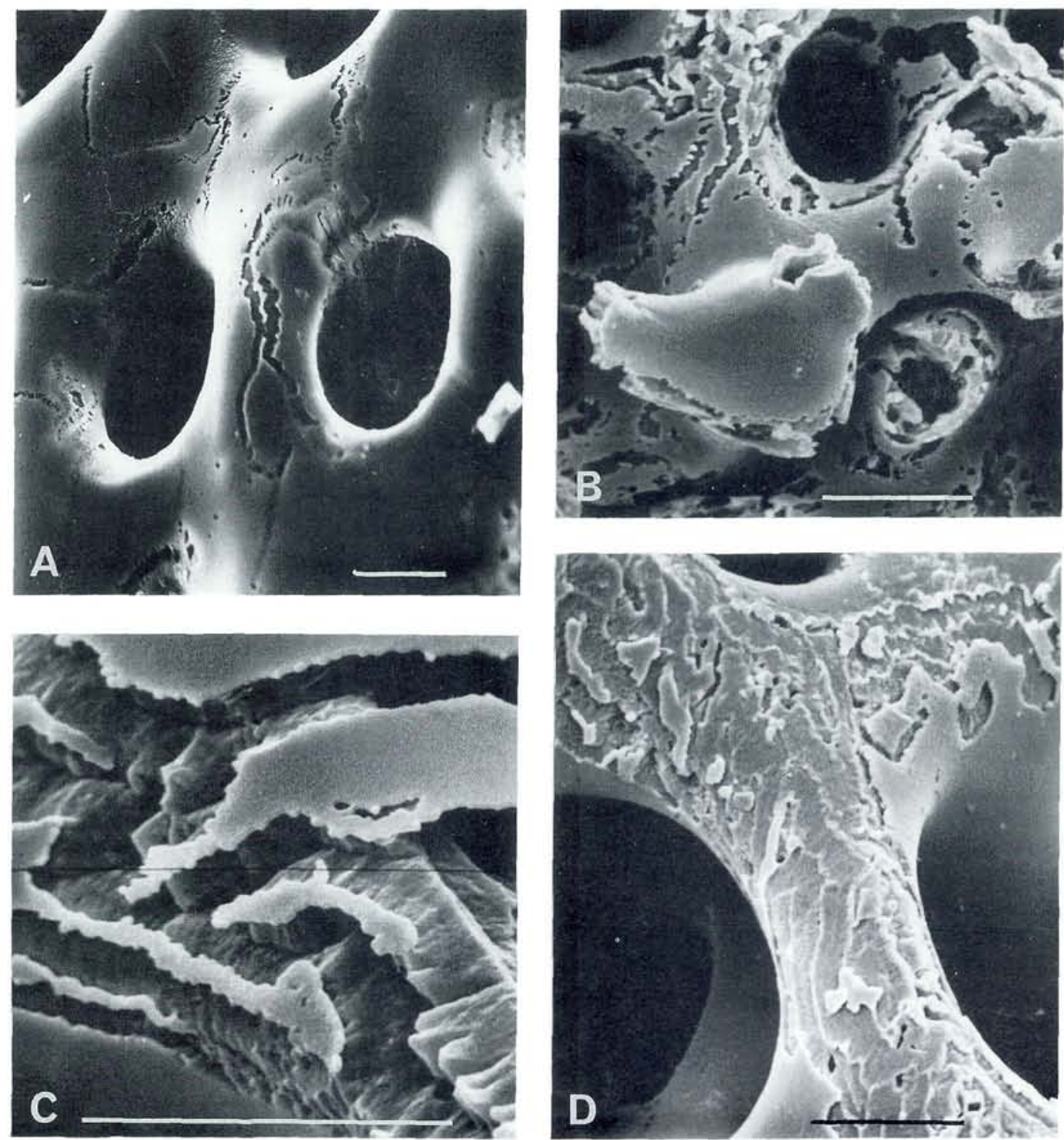

Fig. 8. "Core-and-rind" features in the skeletal trabecular surfaces of fossil Ophiura sarsi ossicles. A. Early stage of dissolution. B. Later stage of dissolution. C. Close up of deep cracks. D. Rather late stage with "core-and-rind" over much of the trabecular surfaces. Scale bar $10 \mu \mathrm{m}$ in $\mathrm{A}$ and $1 \mu \mathrm{m}$ in B-D. 

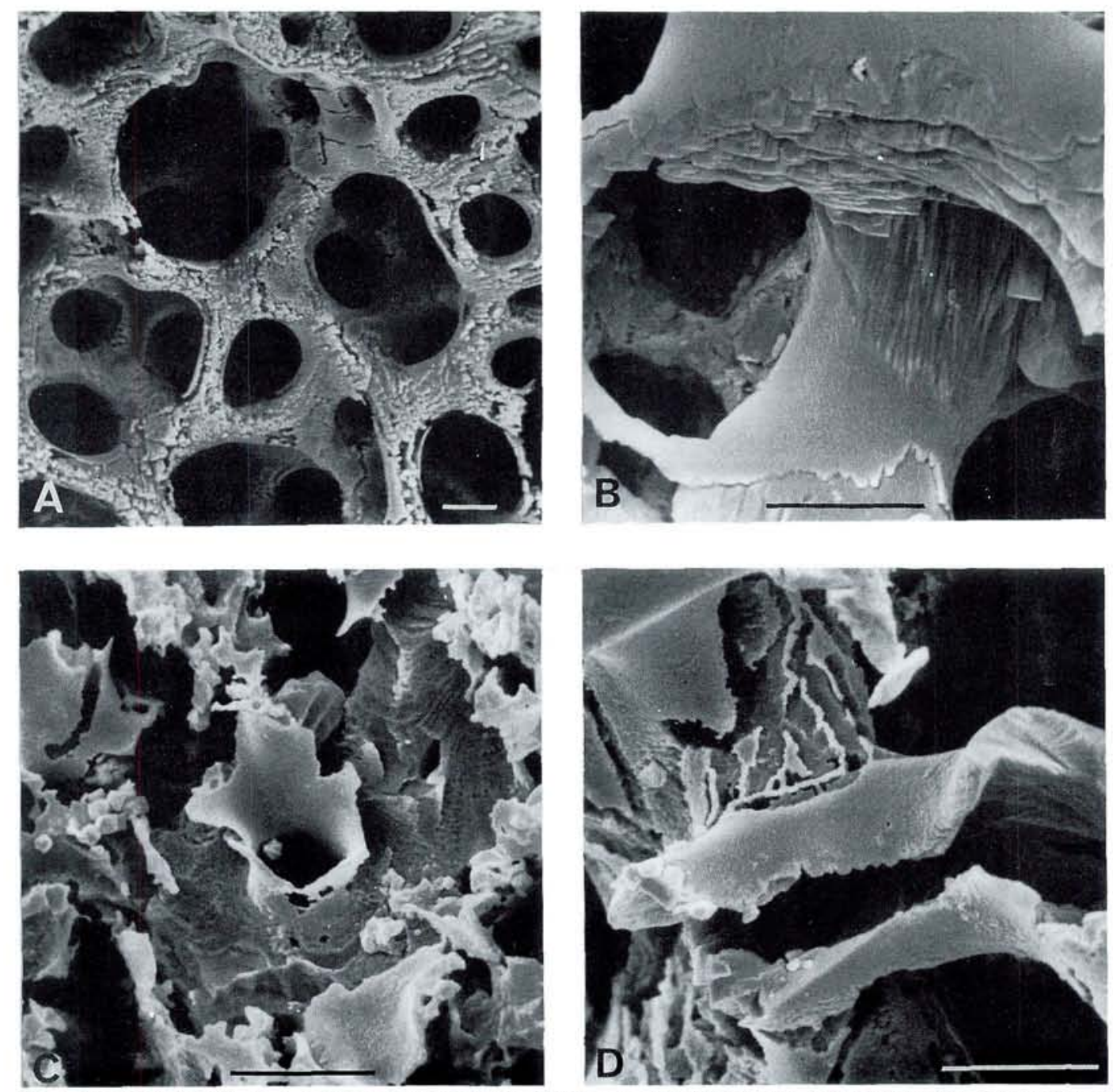

Fig. 9. Continued from fig. 8. A. Later stage of dissolution. B. Close up, depicting ? the lamellar ultrastructure. C. Collar around pores in a very late stage of dissolution. D. Hollow trabecula in a very late stage of dissolution. Scale bar $1 \mu \mathrm{m}$ in A-D.

ferent dissolving agents (table 1) causes a cracking pattern to develop in the compact stereom and in the coarse labyrinthic stereom. This pattern, which has been described by Flessa \& Brown (1983), is quite different from the "coreand-rind" cracks. Besides the cracks, a lot of small pits arise in the etching experiments. These are caused by $\mathrm{CO}_{2}$ bubbles and are also found in the trabeculae surfaces of asteroid ossicles that have passed through the stomach of another asteroid. It is also noteworthy that the polycrystalline lamellar ultrastructure is revealed both by natural and experimental dissolution, in surfaces of fractured and un-fractured trabeculae.

In conclusion, the following dissolution sequence is suggested:

1. Lactic acid accumulates and amino acids are released during the death process and early decay of organic tissue.

2. Holes and cracks are initiated in the sheath and dissolution begins in the unprotected skeletal trabecula surface, initiating "coreand-rind" cracks.

3. Increasing number of cracks are formed and 
older cracks are deepened owing to undersaturation of sea-water with regard to $\mathrm{CaCO}_{3}$.

4. The older central part of the trabeculae falls out (caused by dissolution from the tip, the young skeleton dissolved earlier).

5. Collars remain around pores in the stereom.

\section{"Pyritization"}

Nussman (1975) stated that no pyritization, i.e. replacement of intraskeletal organic matter with pyrite, takes place in echinoderms, because of their continuous-crystal microstructure. The demonstration of the polycrystalline lamellar ultrastructure, e.g. in this study, however, leads to the question of whether organic matter, which may initiate pyritization, is situated within or between the lamellae. As mentioned previously, several authors have found intraskeletal organic matter in the stereom. We did not find any intraskeletal organic matrix using SEM, but an amino acid analysis of ossicles from a Recent $O$. texturata confirms the presence of such. The fact that no pyrite is observed within the ultrastructure, may therefore be explained by the small amount of intraskeletal organic matter and the restricted intercrystalline space. The smallest pyrite granules (known from Recent bivalves) measure $0.1 \mu \mathrm{m}$ (Clark \& Lutz 1980). The intercrystalline space could also be further limited by re- crystallization while the animal was still living and the organic matter thus restricted to the outmost lamellae in the growing trabeculae. Towe (1967) suggested recrystallization as an explanation of the optical single-crystal behaviour.

However, interskeletal pyritization of collagene fibres has been shown by Gaspard \& Roux (1974) in crinoid stereom. They also demonstrated that growth of pyrite framboids in the stereom could break it. Oxidation of the framboids could promote the destruction of the skeleton. Therefore, the presence of pyrite in echinoderm stereom may cause a faster degradation of the skeletal elements than, e.g. in molluscs, which have a less porous skeleton. In this study, framboids are situated in the pores of the stereom, and in secondary voids within the trabeculae (fig. 10A, B). Hence, the "pyritization" of the ossicles must have taken place as a late diagenetic event, following not only the death and disintegration of the ophiurid, but also a period of dissolution, creating the secondary voids in the trabeculae. It is difficult to assess whether the framboids in the stereom are formed simultaneously with those of the trabeculae.
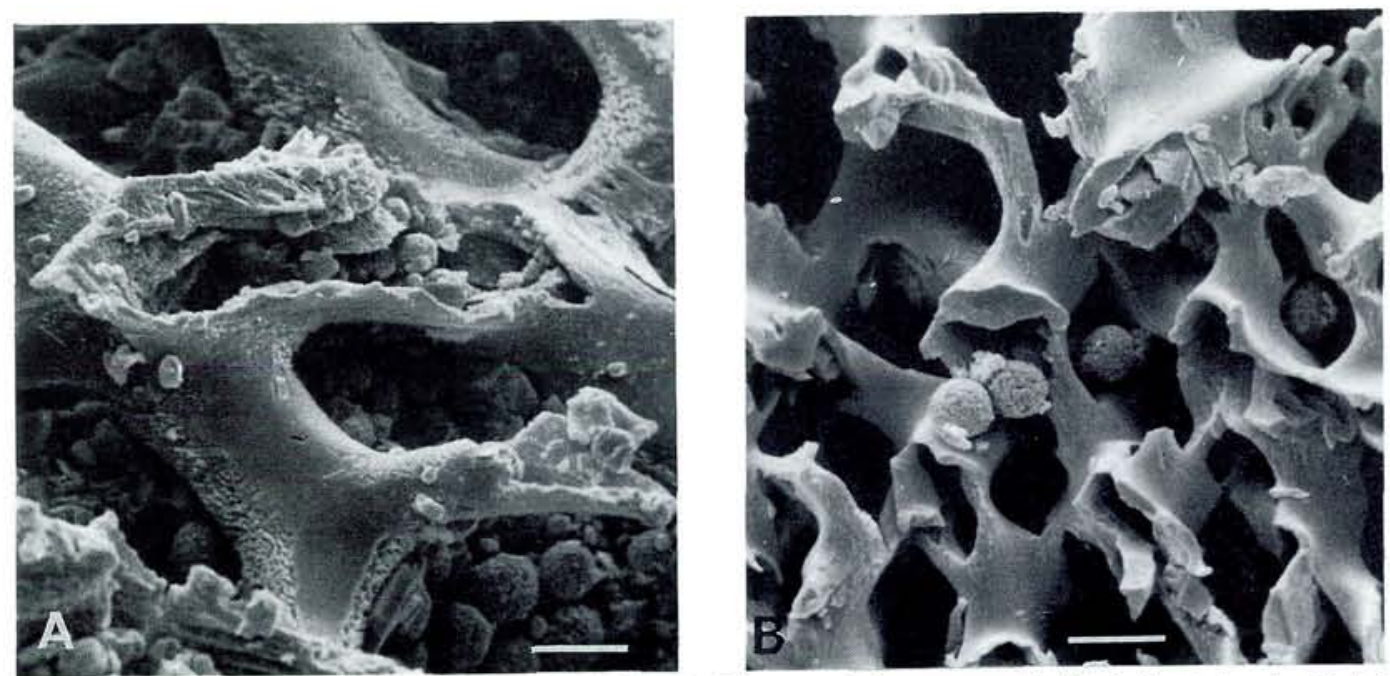

Fig. 10. Pyritization in ossicles of fossil Ophiura sarsi. A. Framboids in pores of the stereom and within hollow trabeculae. B. As in fig. $10 \mathrm{~A}$. Scale bar $1 \mu \mathrm{m}$ in $\mathrm{A}$ and B. 


\section{The diagenetic history and the Late Pleistocene-Holocene environment}

The indication of an oxic cline (oxygen content increasing upwards) in the glaciomarine Late Pleistocene (Thomsen \& Vorren 1986) supports the dissolution sequence (point 3 onwards) as low temperature and high $\mathrm{CO}_{2}$ content lead to undersaturation of $\mathrm{CaCO}_{3}$ (cf. Milliman 1974). However, deep "core-and-rind" structures are also observed in the Holocene material. This implies that the influx of warm, saline and nutrient rich Atlantic water in the Norwegian Current at 10.000 years B.P. did not completely saturate the bottom waters of Andfjorden. This may be due to the increased biogenic production which may consume much oxygen not only for respiration, but also for degradation. To-day, the water masses are relatively well oxygenated throughout the year, also during stratified conditions in the summer season (cf. Sundby 1983). No secondary calcite cement is present in the stereom, sustaining the implication of undersaturated or inert water regime in the area. Alexandersson (1978a) suggested that the shelf regime in middle and high latitudes was inert.

The formation of pyrite demands a reducing environment (cf. Hudson 1982 and Thomsen \& Vorren 1984). This implies that either the entire environment or the microenvironment within the stereom was oxygen depleted. The latter could occur if the ossicles were buried in the reduced zone of the sediment. Because of the porous nature of a stereomic skeleton, it is not likely that an ossicle could contain a reducing microenvironment in an otherwise oxygenated environment, i.e. on the sea-floor or in the topmost sediment layer. As "pyritization" probably followed dissolution (fig. 10A), it cannot have been triggered by the organic remains of the ophiurid in the stereom. It could be referred to detrital organic matter in the sediment or on the sea-bed, perhaps in the form of bacteria.

Framboids are only observed in Late Pleistocene ossicles. The Pleistocene macrofossils demonstrate an Arctic faunal succession that is in principle identical to that of a Recent faunal development in a fjord following an anoxic event (Thomsen \& Vorren 1986). After a period with bioturbating immigrant organisms, the most characteristic elements of the opportunistic Yoldiella intermedia assemblage (14.000-13.000 years B.P.) are pyritized trace fossils. These, which probably originated in tubes and burrows of polychaetes (Thomsen \& Vorren 1984), represent early diagenetic pyritization in an environment that was suffering periodic oxygen deficiency. The Pleistocene material for the present study comes from the suceeding assemblage, the Bathyarca glacialis assemblage (13.000-10.000 years B.P.), that represents an established fauna living during gradually improving oxygen conditions. During the period $12.200-11.100$ years B.P. the pyritized trace fossils almost disappeared, and the environment became fully oxygenated. No ossicles from the period 11.100 10.000 years B.P. have been investigated, because they are very sparse. In conclusion there is no discrepancy between the occurrence of framboids in ossicles from the period 13.000-11.100 years B.P. and the interpretation of the environment. It may be that the pyrite formed during oxygen deficient periods at the sediment-water interface, and was preserved because the ossicles were buried, either by organisms or by sedimentation. Another possibility is that the pyrite formed within the reduced zone of the sediment, but not very deep under the interface because $\mathrm{SO}_{4}^{-}$from the sea-water is needed for the process to take place.

Acknowledgements. This paper was financed by the Norwegian Research Council for Science and the Humanities (grant D. 47.31.29 to professor Dr. T. O. Vorren), by the University of Tromsø and by the Carlsberg Foundation (M.J.). We thank the crew of R/V Johan Ruud for cooperation with core sampling and Mary Raste, Marit Berntsen and Harriet Hansen for laboratory assistance. Scanning electron microscopes were made available by the Micropalaeontological Laboratory and the Zoological Museum, University of Copenhagen, and by the Electron Microscopy Department, University of Troms $ø$. The amino acid analysis was carried out by the Geological Institute, Department B, University of Bergen. Hilka Falkseth drew figs 1-2. We thank Drs. Ulla Asgaard, R. G. Bromley, T. Holthe and N.-M. Hanken for comments on the manuscript.

\section{Dansk sammendrag}

Pighudenes (Echinodermata) skeletdele findes hyppigt i Sen Pleistocæne-Holocæne glaciomarine/marine sedimenter fra den nord-norske kontinentalsokkel (Andfjorden, Malangsdjupet).

Opløsningsstrukturer ("core-and-rind") i fossile skeletdele fra slangestjerner (Ophiura sarsi) fra Andfjorden sammenlignes med naturlige og eksperimentelt udviklede opløsningsstrukturer i skeletdele fra Recente slange- og søstjerner fra danske farvande. 
Pighudenes skelet er opbygget af et netværk (stereom) af skeletstave (trabekler) indlejret i væv (stroma). Trabeklernes ultrastruktur er polykrystallin og lamellar.

Naturlig og eksperimentel opløsning af skeletdele fra Recente pighude viser, at opløsningsstrukturer identiske med "core-and-rind" opløsningsstrukturer i skeletdele fra fossile pighude $(O$. sarsi) udvikles under dyrenes $\mathrm{d} \varnothing \mathrm{d}$ og i det tidligste stadium af forrådnelsen. Det videre opløsningsforløb af skelettet er afhængig af om havvandet er undermættet med karbonat.

Pyrit-framboidre findes i skeletdele fra Sen Pleistocæn, dels i stereomets porer og dels i sekundære hulrum i trabeklerne. "Pyritiseringen" af trabekelhulrummene må have fundet sted efter opløsning, som førte til tab af den centrale, gamle del af trabeklen. Intet pyrit ses i trabeklernes polykrystalline lamellære ultrastruktur. Dette kan enten skyldes den meget begrænsede interkrystalline plads eller rekrystallisation af trabeklernes centrale lag. Den Sen Pleistocæne "pyritisation" fandt sted i et oxygenfattigt miljø.

\section{References}

Alexandersson, E. T. 1975: Etch Patterns on Calcareous Sediment Grains: Petrographic Evidence of Marine Dissolution of Carbonate Minerals. Science, 189, 47-48.

Alexandersson, E. T. 1976: Actual and anticipated petrographic effects of carbonate undersaturation in shallow sea-water. Nature, 262, 653-657.

Alexandersson, E. T. 1978a: Petrographic saturometry in marine carbonate sediments. $S E M, 1,503-511$.

Alexandersson, E. T. 1978b: Destructive diagenesis of carbonate sediments in the eastern Skagerrak, North Sea. Geology, 6, 321-384.

Clark, G. R. \& Lutz, R. A. 1980: Pyritization in shells of living bivalves. Geology, 8, 268-271.

Feder, H. M. 1981: Aspects of the feeding biology of the brittle star Ophiura texturata. Ophelia, 20, 215-235.

Flessa, K. W. \& Brown, T. J. 1983: Selective solution of macroinvertebrate calcareous hard parts: a laboratory study. Lethaia, 16, 193-205.

Gaspard, D. \& Roux, M. 1974: Quelques aspects de la fossilisation des tests chez les brachiopodes et les crinoides. Relation entre la présence de matière organique et le développement d'agrégats ferrifères. Geobios, 7(2), 81-89.

Heatfield, B. M. \& Travis, D. F. 1975: Ultrastructural Studies of Regenerating Spines of the Sea Urchin Strongylocentrotus purpuratus. J. Morph., 145(1), 13-50.

Hudson, J. D. 1982: Pyrite in ammonite-bearing shales from the Jurassic of England and Germany. Sedimentology, 29, 639-667.

Inoué, S. \& Okasaki, K. 1977: Biocrystals. Scient. Am., 236(4), 83-92.

Jensen, M. 1969: Age determination of echinoids. Sarsia, 37, 41-44.

Jensen, M. 1972: The ultrastructure of the echinoid skeleton. Sarsia, 48, 39-48.

Märkel, K. \& Röser, U. 1985: Comparative morphology of echinoderm calcified tissues: Histology and ultrastructure of ophiuroid scales (Echinodermata, Ophiuroida). Zoomorphology, 105, 197-207.

Milliman, J. D. 1974: Marine Carbonates. Recent Sedimentary Carbonates, 1, 375 pp. Springer-Verlag, Berlin, Heidelberg, New York.

Mortensen, T. 1924: Pighude (Echinodermer). Danmarks Fauna, 27, 274 pp. G.E.C. Gads Forlag, København.

Nichols, D. \& Currey, J. D. 1968: The Secretion, Structure, and Strength of Echinoderm Calcite. In: S. M. MacGeeRusell \& K. F. A. Ross (eds.): Cell Structure and its Interpretation, 251-261. Edward Amold (Pub.) Ltd., London.

Nissen, H.-U. 1969: Crystal Orientation and Plate Structure in Echinoid Skeletal Units. Science, 166, 1150-1152.

Nussman, D. G. 1975: Paleoecology and pyritization. Univ. Mich. Mus. Paleontol. Pap. Paleontol., 8, 173-223.

Ockelmann, W. K. \& Muus, K. 1978: The biology, ecology and behavior of the bivalve Mysella bidentata (Montagu). Ophelia, 17, 1-93.

O'Neill, P. L. 1981: Polycrystalline Echinoderm Calcite and Its Fracture Mechanics. Science, 213, 646-648.

Pilkington, J. B. 1969: The organization of skeletal tissues in the spines of Echinus esculentus. J. mar. biol. Ass. U.K. 49, 857-877.

Shimizu, M. \& Yamada, J. 1976: Light and electron microscope observersations of the regenerating test in the sea urchin Strongylocentrotus intermedius. In: N. Watabe \& K. M. Wilbur (eds): The mechanisms of mineralization in the invertebrates and plants. Belle W. Baruch Library in $\mathrm{Ma}$ rine Science, 5, 261-281. Univ. South Carolina Press, Columbia, South Carolina.

Sundby, S. 1983: Influence of bottom topography on the circulation at the continental shelf of northern Norway. Fiskeridirektoratets skrifter, serie Havforskningsundersøkelser, 15 pp.

Thomsen, E. \& Vorren, T. O. 1984: Pyritization of tubes and burrows from Late Pleistocene continental shelf sediments off North Norway. Sedimentology, 31, 481-492.

Thomsen, E. \& Vorren, T. O. 1986: Macrofaunal palaeoecology and stratigraphy in Late Quaternary shelf sediments off northern Norway. Palaeogeography, Palaeoclimatology, Palaeoecology, 56, 103-150.

Towe, K. M. 1967: Echinoderm Calcite: Single Crystal or Polycrystalline Aggregate. Science, 157, 1048-1050.

Travis, D. F. 1969: The structure and organization of, and the relationship between the inorganic crystals and the organic matrix of the echinoderm endoskeleton as it is related to bone. In: Proc. 5th European Symposium on Calcified Tissues, Bordeaux 1967, 399-408. Societe D'Edition D'Enseignement Superieur, Paris.

Travis, D. F. 1970: The comparative ultrastructure and organization of five calcified tissues. In: $\mathrm{H}$. Schraer (ed.): Biological Calcification: Cellular and Molecular Aspect, 203-311. North Holland Publ. Co., Amsterdam.

Weiner, S. 1984: Organization of Organic Matrix Components in Mineralized Tissues. Amer. Zool., 24, 945-951. 